\title{
FACTORS OF ENSURING THE COMPETITIVENESS OF UKRAINE'S PIG BREEDING PRODUCTION IN EXTERNAL MARKETS
}

\author{
M. I. Ibatullin ${ }^{2}$, O.M. Varchenko ${ }^{1}$, I.V. Svynous ${ }^{1}$, \\ O.V. Klymchuk ${ }^{3}$, O.O. Drahan ${ }^{1}$, I.O. Herasymenko ${ }^{1}$ \\ ${ }^{1}$ Bila Tserkva National Agrarian University, 8/1, Soborna Sq, 09117, Ukraine \\ ${ }^{2}$ National University of Life and Environmental Sciences, 11, Heroiv Oborony Str, Kyiv, 03041, Ukraine \\ ${ }^{3}$ Vinnytsia National Agrarian University, 21008, Vinnytsia, Str. Sonyachna, 3, Ukraine,
}

E-mail: omvarchenko@ukr.net, isvinous@ukr.net; klymchukov@ukr.net

Received May 22, 2019 / Received June 07, 2019 / Accepted July 19, 2019

\begin{abstract}
Aim. To substantiate the approaches to activating export transactions in the market of pig breeding products, determining the indicators of competitiveness of the main kinds of meat and relative competitiveness of pig breeding products in the leading countries based on the identification of factors, restraining the export of Ukrainian pig breeding products, and elaborating the suggestions on eliminating their negative impact on the dynamics of foreign economic activity in the industry. Methods. The methodological approaches of the study were based on the information about the volumes of foreign trade, mainly used for international comparison and determined for each commodity or commodity group. The Relative Export Advantage Index (RXA), the Relative Import Penetration Index (RMP) and the Relative Trade Advantage Index (RTA) were determined while estimating competitive advantages of pig breeding products. The study involved a comprehensive comparative analysis of the main kinds of meat products in the external market using the model of "food independence - competitiveness". The index of food independence was used along with the generalizing index of competitiveness for some kinds of meat products - the modified Balassa index. It was determined that it was reasonable to determine the level of food independence based on food selfproduction within the range of 70-80\% from the commodity resources of the domestic food market. Our study involved the data of the informational database of the State Statistics Service of Ukraine and FAO regarding the volume of export-import of pig breeding production. Results. It has been proven that there are no competitive advantages of Ukraine's pig breeding production in external markets; there is insufficient food independence on the background of potential advantages for the expansion of export, in particular, that of cheap fodder and logistics. A considerable decrease in the exchange rate for hryvnia compared to foreign currencies of the leading countries creates prerequisites for successful promotion of Ukrainian pork both in domestic and foreign markets. The need of monitoring the implementation of food independence criteria and diversification of export specialization of the country was substantiated. In the long-term perspective, it is reasonable to optimize the level of protection for the market of pig breeding products, to stimulate domestic production, to distribute the instruments of state support for the "green box". It has been proven that the main directions of supporting the export of domestic agrarian products should become as follows: facilitating export procedures; expanding assortment and accessibility of financial services; developing the supporting infrastructure; informational support for exporters; conducting research and implementing support programs; the activity of the system of credit-insurance institute and trade representations should be carried out in a single complex via determining the potential market and financial-insurance support for the export. Conclusions. The method of two-criteria analysis of the status of domestic market for meat products based on the indices of food safety and international competitiveness has been developed and tested which will promote complex estimation of positions of some kinds of commodities in external market. The model of two-criteria analysis allows substantiating effective instruments of state regulation and protecting the relevant market of products. The method of two-criteria analysis of meat products is universal, i.e. it may be used to determine the positions of different commodity groups in the external market. The evaluation of competitiveness of the main kinds of meat products - pork, beef and poultry meat - demonstrated the absence of competitive advantages of pig breeding production in external markets and insufficient food independence. The factors, restraining the expansion of pork export, were systematized and divided into three main groups: technological; normative and regulatory; veterinary, and the ways of eliminating them were specified. The measures of creating favorable export-institutional environment were elaborated and the main directions of supporting export of domestic pig breeding production were suggested.
\end{abstract}

Keywords: competitive advantages, trade advantages, export, import, pig breeding production, export credit agency, export promotion, export infrastructure.

DOI: https://doi.org/10.15407/agrisp6.02.029

( ) M. I. IBATULLIN, O. M. VARCHENKO, I. V. SVYNOUS, O. V. KLYMCHUK, O. O. DRAHAN, I. O. HERASYMENKO, 2019 


\section{INTRODUCTION}

Considering European integration of domestic economy and implementation of the system of international division of labor, there is a need of accepting and implementing economic leverage of protecting domestic market, ensuring immediate state promotion for small commodity producers, decreasing export fees and ensuring the quality and safety of agrofood. As a result, it is necessary to activate the measures of state regulation for indirect support, such as stimulating scientific research, pest control, conducting measures, aimed at prevention and elimination of African swine fever and other antiepizootic measures of controlling the diseases of animals; training the personnel; providing the services of promoting commodities to external markets; developing infrastructure; governmental involvement in insurance programs and increasing the income of commodity producers; envisaging aid after natural disasters, implementing programs of regional support, etc.

Therefore, the liberalization of agrofood market requires improving the measures of state regulation and elaborating strategies to develop specific industries and commodity markets in a long-term perspective. Taking into consideration the fact that under liberalization conditions the impact of external economic factors on domestic economy is considerable, it is reasonable to use the methods of estimating the effect of foreign trade on the balance of domestic market, determining competitive advantages of commodities and directions of their enhancing and forming new ones to substantiate the strategies of developing commodity markets, including pig breeding production.

It is evident that fiercer competition in the global market of pig breeding production requires revising current approaches to organization and functioning of the system of selling commodities and providing services of promoting the entry of economic subjects into external markets and their activity thereon, based on re-thinking and searching for the directions of minimizing negative effect of the factors, which may be viewed as restraints in the process under investigation. The consideration of the issue of competitive advantages of pig breeding production reveals the urgency of the issues of enhancing the level of adaptability and efficiency of business processes, thus, there is an urgent need of searching for additional possibilities of further decreasing the expenses and cost price of commodities, while increasing the rate of quality. Regardless of the thought that weaker exchange rate of hryvnia may create price-re- lated advantages for domestic pig breeding producers, this advantage should actually be considered as a temporary benefit, which highlights the need to consider the issue of activating export potential of pig breeding industry based on the estimation of competitive advantages of pig breeding products and substantiating the directions of enhancing them and forming new ones. Thus, at present there is a need of conducting a comprehensive analysis of both negative and positive aspects of the results of liberalization and globalization, as well as the analysis of internal possibilities of the industry in terms of expanding quality and safe production and developing and adapting efficient instruments of regulating export transactions which would allow avoiding negative effects and ensuring balanced development of markets for pig breeding production.

It should be noted that the issue of activating export potential of agrarian sector of economy, including pig breeding production, is extremely urgent for both domestic and foreign researchers. Firstly, we would like to consider the positions of domestic scientists who believe that the priority direction of enhancing competitive advantages in foreign markets should be state support for the agrarian sector in the form of developing the marketing aspect of «the green box» of WTO [1]. We share the opinion that the development of instruments of regulating foreign economic activity should envisage careful estimation of export specialization of agrofood complex, giving preference to the export of commodities with high added value [2]. As for the possibilities of forming export potential of pig breeding industry, noteworthy is the position of researchers, who claim that domestic production of pig breeding industry may be competitive in external market due to its high quality and favorable ratio of prices for grain (the main fodder) and live animals [3]. Our evaluation of reviewed scientific studies has yielded a conclusion that there is a current need to diversify external channels of supplying pig breeding products by agricultural producers of commodities on condition of improving epizootic situation in the country. In addition, it should be taken into consideration that both external and internal markets have changed considerably which requires substantiation of strategic approaches to changing the vector of sales for pig breeding products in the external market [4].

While summarizing scientific positions of foreign researchers on the issues of ensuring competitiveness of pig breeding products, it has been established that one of the instruments of achieving long-term competitive 
advantages is deepening integration processes in the chain of supplies of pig breeding products which promotes larger supplies of pork to domestic and external markets and increasing added value [5].

The results of studies of foreign scientists demonstrate that vertical and horizontal integration are of priority significance in enhancing competitiveness while supplying meat to external markets. The presence of two types of industrial systems of pork supplies in the world which are less integrated, for instance, in many western European countries, and industrial systems, based on contracts and vertical integration in such countries as the USA and Denmark, proves the need for more intense vertical coordination, and unstable relations between the chain participants on some European markets are viewed by scientists as an outdated model [6].

It is evident that under conditions of stronger destructive phenomena in pig breeding industry the successful integration of Ukraine into the global market of pig breeding production will be ensured by efficient instruments of state economic regulation of the industry which will promote seizing the potential possibilities, as the country is ranked $24^{\text {th }}$ in the world in terms of pork production, and $6^{\text {th }}$ in terms of pork consuming per one person $-21.5 \mathrm{~kg}$ a year. It is noteworthy that low efficiency indices in pork production and difficulties in ensuring high values of added value are also observed in eastern Europe. For instance, the market of Poland's pig breeding production is remarkable for high volatility of prices which does not provide for stable profitability of pig breeding and the rate of income, received by the operators from the slaughter of pigs. A problem in pig breeding industry of the country is high consumption of fodder per unit of production which conditions excessive use of fodder due to insufficient quality [7]. Noteworthy is the fact that while feeding pigs, most farmers of Poland and Hungary prefer fodder, grown by them, which conditions its imbalance in terms of nutrients [8]. Due to this fact, farmers of the mentioned countries cannot compete with the producers from the leading countries, this problem is getting worse due to unsolved issues in ensuring the quality and safety of commodities, meeting the requirements of biosafety on farms as well as social and ecologic requirements [9].

It should be highlighted that in current conditions the factors of ensuring competitiveness of Ukrainian animal breeding production, including pig breeding, are innovations for all the processes, starting from supplies of material resources and finishing with the delivery of finished products to end customers, following ecologic requirements to the storage and use of by-products and utilization of waste and loss of cattle [10].

Noteworthy is the experience of regulating the market of pig breeding production in Hungary, where a strategic program of industry development has been developed, envisaging the main directions to be the development of pig breeding production on the principles of stability, achieving a balanced industry structure and forming long-term partner relations with all its participants [11]. We believe that the directions, outlined in this program, are of immediate interest for Ukrainian pig breeding industry as well.

It should be noted that at present Poland and Hungary cover domestic consumption with their domestic production. However, in 2009 the rate of meeting the consumers' needs for pig breeding production in Poland was under $100 \%$, mainly due to decreased volumes of production, caused by unfavorable price conditions in previous years. Czech Republic and Slovakia currently do not meet the demand for pork of their domestic markets, which is mainly conditioned by the decreased volumes of production, increased cost price due to higher cost of initial resources [12]. It is evident that the issue of low competitiveness due to high rate of industrial expenses is unsolved in Ukraine as well.

Foreign scientists study the consumers' buying activity in the market of pork and investigate its most important factors - consumers' preferences, volume and distribution of the cumulative income of the household. The obtained results demonstrate high correlation dependence between the level of GDP per person and the consumption of animal proteins per person. It is known that in the past the main purpose for food producers, including pork meat, was production of cheap and safe food. However, these requirements are now covering other relevant factors, including stable production, welfare of animals, ethical procedures, etc. The highest expansion of these requirements is remarkable for European markets. This creates considerable pressure on increasing the expenses of European enterprises which is one of the sources of decreasing their competitiveness in global markets [13].

The entry to external markets requires consideration of specificities of the consumers' buying activity. The studies of European scientists demonstrate that in addition to consumer-oriented characteristics of meat, consumers' income and structure of its distribution, a relevant factor in the markets of EU member-states is ensuring 
high quality and safety of products which is achieved by introducing the system of quality management on all the stages of pig breeding production supplies [14].

Potential possibilities for domestic producers, searching for new market segments, are studied in the field of organic pork. Foreign studies raise the issue of identifying organic products of pig breeding, as, for instance, in Germany a large share of organic products of animal breeding is produced using imported protein fodder. At the moment of selling products of animal origin, the information about the quality of fodder used for their production is usually not indicated. As a result, consumers prefer local organic products of animal breeding, produced using local fodder [15]. Therefore, it is relevant for Ukrainian producers of organic pork to meet the requirements of organic production.

\section{MATERIALS AND METHODS}

Our study involved the data of the informational database of the State Statistics Service of Ukraine and FAO regarding the volume of export-import of pig breeding production. The methodological approaches of the study were based on the information about the volumes of foreign trade, mainly used for international comparison and determined by each commodity or commodity group. As competitiveness is a relative category, the indices, based on absolute values (market share, export volume, etc.) do not provide sufficient information about the competitive position of a particular kind of products or industry in the national economy. We believe that the indices, based on comparing one sector against others, are more informative. It is noteworthy to distinguish the Relative Export Advantage Index (RXA), the Relative Import Penetration Index (RMP) and the Relative Trade Advantage Index (RTA) [16-19] among the indices of estimating competitive advantages of specific kinds of products, most frequently used by foreign scientists.

As the products of pig breeding form consumer needs in meat industry, we consider it reasonable to compare its competitive advantages against beef and poultry. According to this methodological approach, RXA for beef, poultry and pork is determined by the formula: where $X$ - export, $i$ - country, $j$ - commodity, $n$ - total of countries, $k$ - total of commodities.

$$
R X A_{i j}=\left(X_{i j} / \sum_{l, l \neq j} X_{i l}\right) /\left(\sum_{k, k \neq j} X_{k, k, \neq i l, l \neq j} / \sum X_{k l}\right)
$$

The $R X A$ index is determined as the ratio between the country's share in the global export of some kind of meat products (pork, beef, poultry meat) and the share of this country in the global export of all the meat products. It should be stated that the specifics of this estimation lie in the fact that the volume of global export of meat products is always determined as the sum of export of all the countries, except for the one under investigation. Similarly, the sum of the global export is deducted the value of the export of the investigated kind of products which allows avoiding double counting (in case if the volumes of exported meat products of the country are both the numerator and a part of denominator). This aspect is also reasonable if a country has a considerable share in the global trade and/or the investigated kind of products covers a great part of the global export.

RXA index is interpreted as follows: if it is $>1$, the country has comparative advantages in terms of exporting the investigated product, if $R X A<1$, it demonstrates the absence of competitive advantages.

RMP is similar to RXA in its essence with the only difference being that the former index takes into consideration the volumes of import, defined as $M$ :

$$
R M P_{i j}=\left(M_{i j} / \sum_{l, l \neq j} M_{i l}\right) /\left(\sum_{k, k \neq j} M_{k_{k, k \neq i l, l \neq j}} / \sum_{k j}\right),
$$

If the value of $R M P$ is $>1$, the dependence on import is high (there is a competitive disadvantage), if it is $<1-$ it is low (there is a competitive advantage).

It should be noted that RMP may be deceitful (nonobjective), as its value may be considerably distorted due to the effect of protection instruments of the domestic market. It is obvious that on condition of prohibiting import, or using high rates of import levy, this index will reflex a high level of competitive advantages, whereas the contrary notion is fair. A similar drawback is also remarkable for RXA. If, for instance, a country is only a transit country, RXA may reflect a high level of competitive advantages, which will not reflect the reality. From this standpoint, it is relevant to consider what exactly is deemed to be export, as, unfortunately, there are significant differences between countries during accounting and classification of foreign trade transactions.

The indices of export and import of some commodity are taken into consideration simultaneously while estimating RTA, which is made according to the formula:

$$
R T A_{i j}=R X A_{i j}-R M P_{i j}
$$

where $R X A_{i j}$ - the Relative Export Advantage of $i$ commodity in $j$-country; $R M P_{i j}$ - the Relative Import Penetration of the import of $i$-commodity in $j$-country. 
Here, the positive value of this index indicates relative advantages in foreign trade, and the negative one - relative disadvantages. Obviously, it is important to use the volumes of both export and import in the estimations of competitiveness, taking into consideration the increase in the volumes of intra-industry trade.

We have conducted a comprehensive comparative analysis of the main kinds of meat products in the external market by the model of «food independence - competitiveness». We have taken the index of food independence $(F)$ as an index of food independence:

$$
F=\ln \left(\frac{p^{*} 100 \% \div\left(m+p^{*} s-x\right)}{n}\right)
$$

where, $x$ - volumes of exporting a specific kind of meat products from the country; $m$ - volumes of importing a specific kind of meat products into the country; $p$ - volumes of domestic production of a specific kind of meat products in the country; $s$ - change in the volumes of stock of a specific kind of meat products in the country; $n$ - a minimal share of a specific kind of meat products of domestic production.

We believe that the modified Balassa index, i.e. one of the variants of comparative advantages (RCA), should be accepted as an index of competitiveness:

$$
R C A=\ln \frac{\left(x_{i j}: m_{i j}\right)}{\Sigma x_{i j}: \Sigma m_{i j}} * 100
$$

$x_{i j}$ - volumes of exporting a specific kind of meat products $(j)$ from the country $i$; $m_{i j}$ - volumes of importing a specific kind of meat products $(j)$ into the country $i$; $\Sigma x_{i j}$ - cumulative volume of export of meat products from the country $i ; \Sigma m_{i j}$ - cumulative volume of import of meat products into the country $i$.

The use of natural logarithm in calculating both indexes widens the possibilities of cluster analysis, as it will allow distributing the values of indexes of food independence $(F)$ and revealing comparative advantages $(R C A)$ in the area of positive and negative values. This approach will facilitate the comparison of indexes $F$ and $R C A$, which will provide for clear division of food products into clusters.

Let us apply the results of two-criteria analysis for food market to the plane with the axis of abscissa, which corresponds to the index of food independence $(F)$, and the axis of ordinates, which corresponds to the index of revealed (open) comparative advantages $(R C A)$.
The vertical and horizontal lines, corresponding to the threshold values of the criterion, are drawn on the coordinate plane to conduct the analysis. Threshold values become evident due to the use of both indexes of a natural logarithm in the formulas. It should be noted that another approach may be used to determine threshold values of the criteria. For instance, the average indices by the investigated sampling may be accepted as threshold values, which will allow dividing the coordinate space into segments in a more proportional way.

The determination of a maximal (minimal) admissible level for each index is a relevant methodological issue. As for the index of food independence, if the share of agricultural raw material and food of own production in the total volume of commodity resources of domestic market exceeds the set normative index, then $F>0$. In case of excessive import dependence and decrease in domestic production to the level, set by the government of the country, $F<0$.

In our estimates the minimally admissible level of food independence may be interpreted in different ways for different food products depending on the level, on which food provision for the market based on own production may or should be achieved. It is evident that the level of food independence in the industry is deemed to be self-production within the range of $70-80 \%$ from the commodity resources of the domestic food market.

In addition to the mentioned methodological approach, while conducting this study we have used general and special economic methods: induction and deduction, generalizing the systemic approach to phenomena while determining the factors and vector of their effect on potential possibilities of activating export activity in pig breeding as well as statistical-economic method while studying the dynamics of export and import of meat products of Ukraine.

\section{RESULTS AND DISCUSSION}

According to the forecast of the US Department of Agriculture, in 2019 the global pork production will increase by $1 \%$ and amount to 114.6 million tons due to the increase in the production volumes of China and the USA. This situation is conditioned by the increasing consumers' demand for pork in most countries. However, the spreading of African swine fever in the world has led to slowing down the tempo of increasing the production volumes compared to the previous year. It is noteworthy that there is a forecast increase in the global export by $3 \%$ due to higher global demand and decrease in the prices for pork, although in 2018 
the volumes of global export increased by $6 \%$ [20]. However, current situation in the global market demonstrates potential possibilities for domestic producers in terms of export which may be possible on condition of enhancing its competitive advantages both in the domestic and external markets.

At the same time, global volumes of export in 2019 are forecast $8 \%$ higher compared to the previous year, which is conditioned by higher demand from China and stable economic growth in most major markets of pork. It should be noted that EU member-states will remain the largest exporters, the volumes of supplies of which increased by $11 \%$ compared to the previous year. The countries, ensuring the fastest increase in pork export, starting from 2013, have been as follows: Hong Kong (by $214.3 \%$ ), Spain (by $28.3 \%$ ), Brazil (19.4\%), Ireland (19.1\%) and Mexico (18.7\%) [21].

China remains the country with the highest demand, the forecast of the increase in import volumes is $41 \%$ due to the decrease in domestic production because of African swine fever. A similar tendency is forecast regarding Japan, which will also increase her import due to high demand for red meat. The decrease in tariffs within the framework of new free trade agreements will also stimulate the demand for pork in Canada and EU. After record-high 2018, Korea will decrease its import due to large reserves and increasing competition from its domestic production [22]. Taking into consideration the trends of development of global pork market requires determining actual positions of Ukrainian agents thereon and scientific substantiation of realizing non-used possibilities in enhancing international competitiveness.

Let us consider the tendencies of export-import of meat products, including pig breeding products, in Ukraine (Table 1). The data in Table 1 demonstrate that in 2018 over $88.3 \%$ of export volumes was poultry meat, and the supplies of meat products of pig breeding took an insignificant share, which proves the need to substantiate the directions of enhancing competitive advantages of the products in external markets.

At the same time, foreign economic activity of domestic agents in selling pig breeding products in 2018 was rather controversial both for Ukrainian pig breeding and exporters. The external supplies of fresh, cooled and frozen pork slowed down compared to 2017 and lagged behind the volumes of intake of imported pork considerably. Thus, the stabilization of prices at the new level of domestic procurement prices for pigs in slaughter condition in 2018 conditioned a slowdown of export activity of domestic operators, on the one hand, and activation of pork import, on the other hand. As a result, in 2018 foreign trade balance of Ukraine in terms of pig breeding products was negative and amounted to USD 104,368 thousand.

We believe that domestic commodity producers have potential perspectives of expanding their export of pig breeding products in the form of relatively cheap fodder and logistics, but these possibilities are not used to the fullest degree. For instance, Denmark has a higher density of pigs, but these are fed with Ukrainian grain and Brazilian soybean meal. We share the opinion of some scientists that domestic operators do not realize the potential possibilities while creating added value in the sphere of supplies of pig breeding industry, including animal breeding industry as a whole [23]. It is evident that the use of grain products as fodder in animal breeding will allow creating new jobs, increasing product offers for different kinds of meat products, enhancing the added value which will promote enhancing the efficiency of specific participants and budget efficiency.

When Ukraine enters the Free-trade zone, the price for Ukrainian pork will decrease considerably, and the cost of fodder will increase instead. According to the experts, one of the factors, restraining export, is imperfection of approaches to the technologies of managing domestic pig breeding, organization of management accounting and controlling the quality and safety of

Table 1. The dynamics of the volumes of export and import

\begin{tabular}{l|c|c}
\hline \multicolumn{1}{c}{ Kinds of products } & 2008 & 2009 \\
\hline \multicolumn{3}{c}{ Export } \\
\hline Beef and veal & 16815 & 18918 \\
Pork & 8 & 4 \\
Poultry meat & 8366 & 18935 \\
Share of poultry meat, \% & 33.2 & 50.0 \\
\hline \multicolumn{3}{c}{ (mport } \\
\hline Beef and veal & 31017 & 13616 \\
Pork & 225056 & 222846 \\
Poultry meat & 256085 & 193228 \\
Share of poultry meat, \% & 50.0 & 45.0 \\
\hline \multicolumn{3}{c}{ Balance } \\
\hline Beef and veal & -14202 & 5302 \\
Pork & -225048 & -222842 \\
Poultry meat & -247719 & -174293 \\
\hline
\end{tabular}

Note. Source: composed and estimated according to the 
products. However, a considerable decrease in the exchange rate for hryvnia compared to foreign currencies of the leading countries creates prerequisites for successful promotion of domestic pork both in domestic and foreign markets. Let us conduct comparative analysis of procurement prices for pork in several countries to prove this conclusion.

The results of our research demonstrate that regardless of global tendencies of decrease in the level of procurement prices for pork, the remarkable fact about Ukraine is that due to considerable depreciation of hryvnia compared to the leading currencies of the world, the rate of procurement prices is less than 1 euro/kg of live bodyweight. This circumstance creates favorable conditions for increasing the volumes of production and export of pig breeding products by domestic commodity producers. It should be highlighted that since Ukraine's entrance to WTO there is an active basic tariff quota for the supplies of domestic pork to the external market in the amount of 20 thousand tons a year and an additional tariff quota of 20 thousand tons. In case of exceeding the quota volume, there is a basic rate of entrance levy, which depends on products and may fluctuate from 46.7 to 86.9 euro/100 $\mathrm{kg}$ of net weight. Live animals have «zero» duty for export to the EU [24].

In addition, to sell live animals in the EU, Ukraine should have a relevant permission and approved veterinary certificates, which are currently absent [25].
It is known that foreign economic activity is conducted within the framework of classic international theories, in particular, the model of comparative advantages and the theory of the ratio of production factors [16]. A relevant aspect of the theory of comparative advantages is their dynamic nature; comparative advantages are not static, they may become weaker or stronger with time, including the effect of economic state regulation. The efficiency of the arms of regulating foreign economic activity of the subjects of pig breeding industry requires constant analysis of the dynamics in the change of comparative advantages, which allows substantiating the directions and mechanisms.

One of the best-known methods of revealing competitive advantages of the country is Balassa index, developed by the American economist Balassa in 1965 [17]. Among the indices, most frequently used by foreign scientists, noteworthy are the Relative Export Advantage Index $(R X A)$, the Relative Import Penetration Index $(R M P)$ and the Relative Trade Advantage Index $(R T A)$.

We believe that it is reasonable to estimate the volumes of both export and import, i.e. the tendencies of intra-industry trade, while estimating the competitiveness of a particular kind of products. To estimate the competitiveness of pork, beef and poultry meat, we estimated the indexes, characterizing relative competitive advantages in 2008-2016 in the study (Table 2). of meat products of Ukraine, thousands of US dollars

\begin{tabular}{|c|c|c|c|c|c|c|c|c|}
\hline 2010 & 2011 & 2012 & 2013 & 2014 & 2015 & 2016 & 2017 & 2018 \\
\hline \multicolumn{9}{|c|}{ Expor } \\
\hline $\begin{array}{c}13388 \\
611 \\
32457 \\
69.9 \\
\end{array}$ & $\begin{array}{c}12993 \\
12510 \\
49789 \\
66.1 \\
\end{array}$ & $\begin{array}{c}16670 \\
20208 \\
80653 \\
68.6 \\
\end{array}$ & $\begin{array}{c}23661 \\
4619 \\
145458 \\
83.7 \\
\end{array}$ & $\begin{array}{c}21497 \\
9362 \\
174727 \\
85.0 \\
\end{array}$ & $\begin{array}{c}32065 \\
27169 \\
161284 \\
73.1 \\
\end{array}$ & $\begin{array}{c}35084 \\
3161 \\
240163 \\
86.3 \\
\end{array}$ & $\begin{array}{c}41875 \\
4923 \\
271327 \\
85.3 \\
\end{array}$ & $\begin{array}{c}41772 \\
1756 \\
328968 \\
88.3 \\
\end{array}$ \\
\hline \multicolumn{9}{|c|}{ Import } \\
\hline $\begin{array}{c}24799 \\
169360 \\
154618 \\
44.3 \\
\end{array}$ & $\begin{array}{c}23101 \\
126470 \\
61096 \\
29.0 \\
\end{array}$ & $\begin{array}{c}15864 \\
272677 \\
114604 \\
28.4 \\
\end{array}$ & $\begin{array}{c}14966 \\
215481 \\
71081 \\
23.6 \\
\end{array}$ & $\begin{array}{c}11137 \\
118272 \\
60986 \\
32.0 \\
\end{array}$ & $\begin{array}{c}11173 \\
78735 \\
61252 \\
40.5 \\
\end{array}$ & $\begin{array}{c}9752 \\
63268 \\
83296 \\
53.3 \\
\end{array}$ & $\begin{array}{c}9586 \\
74843 \\
118310 \\
58.4 \\
\end{array}$ & $\begin{array}{c}10889 \\
106124 \\
130458 \\
52.7 \\
\end{array}$ \\
\hline \multicolumn{9}{|c|}{ Balance } \\
\hline $\begin{array}{c}-11411 \\
-168749 \\
-122161\end{array}$ & $\begin{array}{c}-10108 \\
-113960 \\
-11307\end{array}$ & $\begin{array}{c}806 \\
-252469 \\
-33951\end{array}$ & $\begin{array}{c}8695 \\
-210862 \\
74377\end{array}$ & $\begin{array}{c}10360 \\
-108910 \\
113741\end{array}$ & $\begin{array}{c}20892 \\
-51566 \\
100032\end{array}$ & $\begin{array}{c}25332 \\
-60107 \\
156867\end{array}$ & $\begin{array}{c}32289 \\
-69920 \\
153017\end{array}$ & $\begin{array}{c}30883 \\
-104368 \\
198510\end{array}$ \\
\hline
\end{tabular}

data of the State Statistics Service of Ukraine. 
The estimations in Table 2 demonstrate that the main kinds of meat products under our investigation have comparative advantages in terms of export. It should be noted that the highest value of RXA was obtained for poultry meat $(0.52)$ and the lowest one - for beef and veal $(0.07)$. The estimated value of RTA for pig breeding products was negative $(-0.461)$ in 2016 which demonstrated its relative disadvantages and required substantiating the instruments of enhancing its export potential.

The study revealed that, contrary to other markets of meat products, the domestic market of pork has a high level of dependence on import. Let us analyze the indexes of relative competitiveness of pork in other countries (Table 3).

The results of our estimates demonstrate that the highest level of competitiveness is remarkable for pig breeding producers of Denmark. Other countries are sensitive to the import of this product onto their domestic markets.
The model of two-criteria analysis of meat products market - «food independence-competitiveness» was used by us for the purpose of more detailed analysis of competitiveness of pork meat. This model is the basis for the method of substantiating the priority measures of protecting the investigated market and allows evaluating the efficiency of using and correcting them in time.

The model of two-criteria analysis of meat products market - «food independence-competitiveness» allows us to estimate separate commodity groups. It should be highlighted that the economic essence of the threshold value for the index of revealed (open) comparative advantages of the industry (RCA) is based on the capability of the industry to fill the domestic and external markets with the products of domestic production more successfully than foreign competitors do.

We used the index of RTA and modified Balassa index, which allow determining the tendency in form-

Table 2. The indexes of relative competitiveness of the main kinds of meat in Ukraine

\begin{tabular}{|c|c|c|c|c|c|c|c|c|c|}
\hline \multirow{2}{*}{ Index } & \multicolumn{9}{|c|}{ Year } \\
\hline & 2008 & 2009 & 2010 & 2011 & 2012 & 2013 & 2014 & 2015 & 2016 \\
\hline \multicolumn{10}{|c|}{ Pork } \\
\hline $\begin{array}{c}R X A \\
R M A \\
R T A \\
\end{array}$ & $\begin{array}{c}3.78 \\
0.000 \\
-3.777 \\
\end{array}$ & $\begin{array}{c}3.47 \\
0.000 \\
-3.473\end{array}$ & $\begin{array}{c}3.15 \\
0.015 \\
-3.137\end{array}$ & $\begin{array}{c}1.60 \\
0.195 \\
-1.406 \\
\end{array}$ & $\begin{array}{c}3.89 \\
0.223 \\
-3.666 \\
\end{array}$ & $\begin{array}{c}3.50 \\
0.054 \\
-3.447 \\
\end{array}$ & $\begin{array}{c}1.53 \\
0.069 \\
-1.463 \\
\end{array}$ & $\begin{array}{c}0.91 \\
0.183 \\
-0.726 \\
\end{array}$ & $\begin{array}{c}0.48 \\
0.015 \\
-0.461 \\
\end{array}$ \\
\hline \multicolumn{10}{|c|}{ Beef and veal } \\
\hline $\begin{array}{c}R X A \\
R M A \\
R T A\end{array}$ & $\begin{array}{c}0.14 \\
0.186 \\
0.049\end{array}$ & $\begin{array}{c}0.12 \\
0.200 \\
0.081\end{array}$ & $\begin{array}{c}0.25 \\
0.197 \\
-0.052\end{array}$ & $\begin{array}{c}0.21 \\
0.160 \\
-0.053\end{array}$ & $\begin{array}{c}0.15 \\
0.140 \\
-0.015\end{array}$ & $\begin{array}{c}0.16 \\
0.172 \\
0.013\end{array}$ & $\begin{array}{c}0.10 \\
0.129 \\
0.025\end{array}$ & $\begin{array}{c}0.09 \\
0.161 \\
0.069\end{array}$ & $\begin{array}{c}0.07 \\
0.160 \\
0.091\end{array}$ \\
\hline \multicolumn{10}{|c|}{ Poultry } \\
\hline $\begin{array}{c}R X A \\
R M A \\
R T A\end{array}$ & $\begin{array}{c}3.42 \\
0.053 \\
-3.372\end{array}$ & $\begin{array}{c}2.54 \\
0.104 \\
-2.437\end{array}$ & $\begin{array}{c}2.54 \\
0.280 \\
-2.265\end{array}$ & $\begin{array}{c}0.55 \\
0.319 \\
-0.232\end{array}$ & $\begin{array}{c}1.28 \\
0.413 \\
-0.865\end{array}$ & $\begin{array}{c}0.77 \\
0.706 \\
-0.065\end{array}$ & $\begin{array}{c}0.58 \\
0.856 \\
0.272\end{array}$ & $\begin{array}{c}0.67 \\
0.839 \\
0.171\end{array}$ & $\begin{array}{c}0.52 \\
1.061 \\
0.541\end{array}$ \\
\hline
\end{tabular}

Note. Source: calculated using the data of the Food and Agriculture Organization (FAO) of the United Nations and the State Statistics Service of Ukraine.

Table 3. The indexes of relative competitiveness of pork in several countries, 2016

\begin{tabular}{c|c|c|c|c|c|c}
\hline Index & Denmark & Belarus & Poland & Russia & Ukraine & China \\
\hline$R X A$ & 10.006 & 1.150 & 2.321 & 0.004 & 0.48 & 0.351 \\
$R M A$ & 0.889 & 3.395 & 5.501 & 2.777 & 0.015 & 0.567 \\
$R T A$ & 9.117 & -2.245 & -3.180 & -2.773 & -0.461 & -0.216 \\
\hline
\end{tabular}

Note. Source: calculated using the data of the Food and Agriculture Organization (FAO) of the United Nations. 
ing the competitive advantages of the investigated products, as an index of competitiveness of the main kinds of meat products. The estimation of the indexes of comparative advantages and food independence of the main kinds of meat products is presented in Table 4.

The data, presented in Table 4, demonstrate that the highest indexes of revealed competitive advantages $(R C A)$ were found for beef and veal in $2017-1.201$, and the index of food independence was 0.173 (during 2008-2017 it was 0.0764), which proved its low level that may lead to the loss of food independence on condition of the absent rational combination of market self-regulation and instruments of state regulation of the market of beef and veal. It is obvious that enhancing competitive advantages in the external market in terms of this kind of product is ensured due to the decrease in the purchasing ability of the country's population which conditioned the formation of export potential, however, it should be stated that rational satisfaction of consumers' needs in this kind of meat was not achieved. This is proven by average values of achieved competitive advantages of beef and veal during 2008-2017, which amounted to 0.0764 only. This situation demonstrates that the use of this methodological approach to estimating competitive advantages of the products in external markets requires considering the actual level of meeting the needs in each competitive case in order to achieve substantiated conclusions.

As for poultry meat, the modified index of competitive advantages was 0.666 in 2017 in case of achieving food independence -0.236 . It should be noted that in recent two years there has been a considerable increase (almost two-fold) in the index of food independence due to the expansion of industrial capacities of poultry meat production and increased export of poultry meat. However, there are considerable delivery volumes of this kind of product into the country, mostly cheap raw material for processing enterprises, and trainings.

A contrary situation regarding the competitiveness of products was determined for pork meat, where the value of the modified Balassa index in 2017 was -3.021. Thus, pork does not have international competitiveness and there are considerable volumes of taking this kind of products onto the domestic market. The obtained value of the food independence index of -0.019 is critical which demonstrates the dependence on external supplies of this product. Taking into consideration the tendency to decreasing meat production volumes of agricultural enterprises and personal households and on condition of increasing the purchasing ability of population, there may arise a situation of losing food independence. We believe that the most complicated situation is in the market of pig breeding products which conditions the need of substantiating efficient instruments of increasing commodity supply for this kind of products and forming export potential.

Following the results of comparative analysis of the main commodity groups of meat products in the context of indexes of RTA and food independence we can come to the following conclusions.

Table 4. The dynamics of the indexes of comparative advantages and food independence of the main kinds of meat products

\begin{tabular}{|c|c|c|c|c|c|c|c|c|c|c|}
\hline Kind of products & 2008 & 2009 & 2010 & 2011 & 2012 & 2013 & 2014 & 2015 & 2016 & 2017 \\
\hline \multicolumn{11}{|c|}{ Beef and veal } \\
\hline $\begin{array}{l}\text { Index of food independence } \\
\text { Balassa index (for the group } \\
\text { of agroindustrial products) }\end{array}$ & $\begin{array}{l}0.014 \\
0.515\end{array}$ & $\begin{array}{l}0.039 \\
0.686\end{array}$ & $\begin{array}{c}0.046 \\
-0.006\end{array}$ & $\begin{array}{c}0.040 \\
-0.106\end{array}$ & $\begin{array}{l}0.040 \\
0.111\end{array}$ & $\begin{array}{l}0.065 \\
0.274\end{array}$ & $\begin{array}{l}0.069 \\
0.435\end{array}$ & $\begin{array}{l}0.105 \\
0.743\end{array}$ & $\begin{array}{l}0.128 \\
0.919\end{array}$ & $\begin{array}{l}0.173 \\
1.201\end{array}$ \\
\hline \multicolumn{11}{|c|}{ Pork } \\
\hline $\begin{array}{l}\text { Index of food independence } \\
\text { Balassa index (for the group } \\
\text { of agroindustrial products) }\end{array}$ & $\begin{array}{l}-0.010 \\
-9.111\end{array}$ & $\begin{array}{l}-0.007 \\
-9.453\end{array}$ & $\begin{array}{c}0.005 \\
-5.091\end{array}$ & $\begin{array}{c}0.024 \\
-1.928\end{array}$ & $\begin{array}{c}0.024 \\
-2.621\end{array}$ & $\begin{array}{c}0.010 \\
-3.889\end{array}$ & $\begin{array}{c}0.021 \\
-2.841\end{array}$ & $\begin{array}{c}0.050 \\
-1.380\end{array}$ & $\begin{array}{c}0.016 \\
-3.361\end{array}$ & $\begin{array}{c}0.019 \\
-3.021\end{array}$ \\
\hline \multicolumn{11}{|c|}{ Poultry meat } \\
\hline $\begin{array}{l}\text { Index of food independence } \\
\text { Balassa index (for the group } \\
\text { of agroindustrial products) }\end{array}$ & $\begin{array}{l}-0.019 \\
-3.958\end{array}$ & $\begin{array}{c}0.013 \\
-3.027\end{array}$ & $\begin{array}{c}0.024 \\
-1.996\end{array}$ & $\begin{array}{c}0.055 \\
-0.434\end{array}$ & $\begin{array}{c}0.055 \\
-0.945\end{array}$ & $\begin{array}{l}0.139 \\
0.097\end{array}$ & $\begin{array}{l}0.166 \\
0.555\end{array}$ & $\begin{array}{l}0.146 \\
0.373\end{array}$ & $\begin{array}{l}0.215 \\
0.775\end{array}$ & $\begin{array}{l}0.236 \\
0.666\end{array}$ \\
\hline
\end{tabular}

Note. Source: estimated according to the data of the State Statistics Service of Ukraine. 
The obtained results demonstrate that poultry meat has higher competitiveness in the group of meat products, ensuring the index of comparative advantages of 0.541 in 2016 and that of food independence -0.215 . At the same time, beef and veal have a lower level of competitive advantages in external markets -0.145 with food independence of 0.128 which is conditioned by the deceitful situation regarding the formation of export potential in the industry due to limited purchasing capability of the country in terms of meeting the needs for this kind of meat. These data demonstrate that pork meat is not competitive in the international markets as the index of competitiveness is -0.456 with the critical level of food independence -0.016 .

As for the results of comparative analysis of the main commodity groups of meat products by the modified Balassa index of comparative advantages $(R C A)$ and food independence, they confirm the abovementioned conclusions.

In 2017 Balassa index for poultry meat was 0.666 and that of food independence -0.236 . It should be noted that this kind of products requires efficient instruments of supporting export activity of commodity producers based on the activation of the infrastructure of foreign economic activity, stimulation of domestic demand until achieving rational consumption.

As for beef and veal, there was high international competitiveness -1.201 and low food independence - 0.128 which demonstrates competitiveness and increased demand for this kind of products in the external market. However, a considerable external demand and limited domestic demand stimulates export and may create deficit in the domestic market. This situation may pose a threat to the domestic food provision and result in considerable financial expenses for import, severe crisis in adjacent and processing industries, which requires state measures to expand the production volumes for beef and veal as well as to stimulate consumers' demand.

There is a threatening situation with pig breeding production which is not competitive in external markets according to the estimated Balassa index --3.021 and has critical food independence -0.019 . We believe that state management bodies should monitor the implementation of food independence criteria and adjust the priorities of export specialization. In the longterm perspective, it is reasonable to optimize the level of protection for the market of pig breeding products, to stimulate domestic production, to replace the subsidies within the «yellow box» with the instruments of the «green box», etc. In case of low efficiency of state instruments of regulating the market of pig breeding products, there may arise a negative situation when production volumes will be insufficient and driven out by import goods flows. Therefore, food independence of the country in terms of this kind of meat products will be under the threat, and the main countermeasures should be market protection instruments.

Thus, having applied different methodological approaches to estimating international competitiveness of Ukrainian meat products, we have come to the conclusion about non-competitiveness of pig breeding products in external markets, which brings up-to-date and proves the need to substantiate the instruments of state impact on enhancing the efficiency of pork production and implementing the possibilities of expanding its export.

We believe that the research of foreign trade transactions in the market of pig breeding products should consider the effect of illegal, so called «gray», import of pork meat on the balance of the market of pig breeding products. According to our estimates, it covered about $35-40 \%$ in the structure of raw materials, coming for the production of meat products and sausages in 2015-2018 [26]. This index has decreased considerably within recent two years. The main consumers of such raw material are small meat-processing enterprises. It is evident that such competition is destructive for domestic meat market, most agricultural enterprises will become unprofitable, and small commodity producers may terminate their activity.

The obtained results of estimating competitive advantages of pork meat require substantiating the directions of enhancing them in the external market. It would be reasonable to divide all the factors, restraining the expansion of pork export, including export to the EU member-states, into three main groups: technological, normative and regulatory, veterinary (Figure).

At present most agricultural enterprises and households use simplified technologies of pig feeding, thus receiving fat pork as a slaughter product, which is not in demand with the end consumer in the EU memberstates. Therefore, agricultural commodity producers should change the technologies of pig breeding production, mainly the species composition of agricultural animals, choosing the species, specialized types and lines of pigs of meat and bacon breeds.

Traditionally, liquid and dry fodder is used to feed pigs. High daily gain may be achieved using liquid fod- 


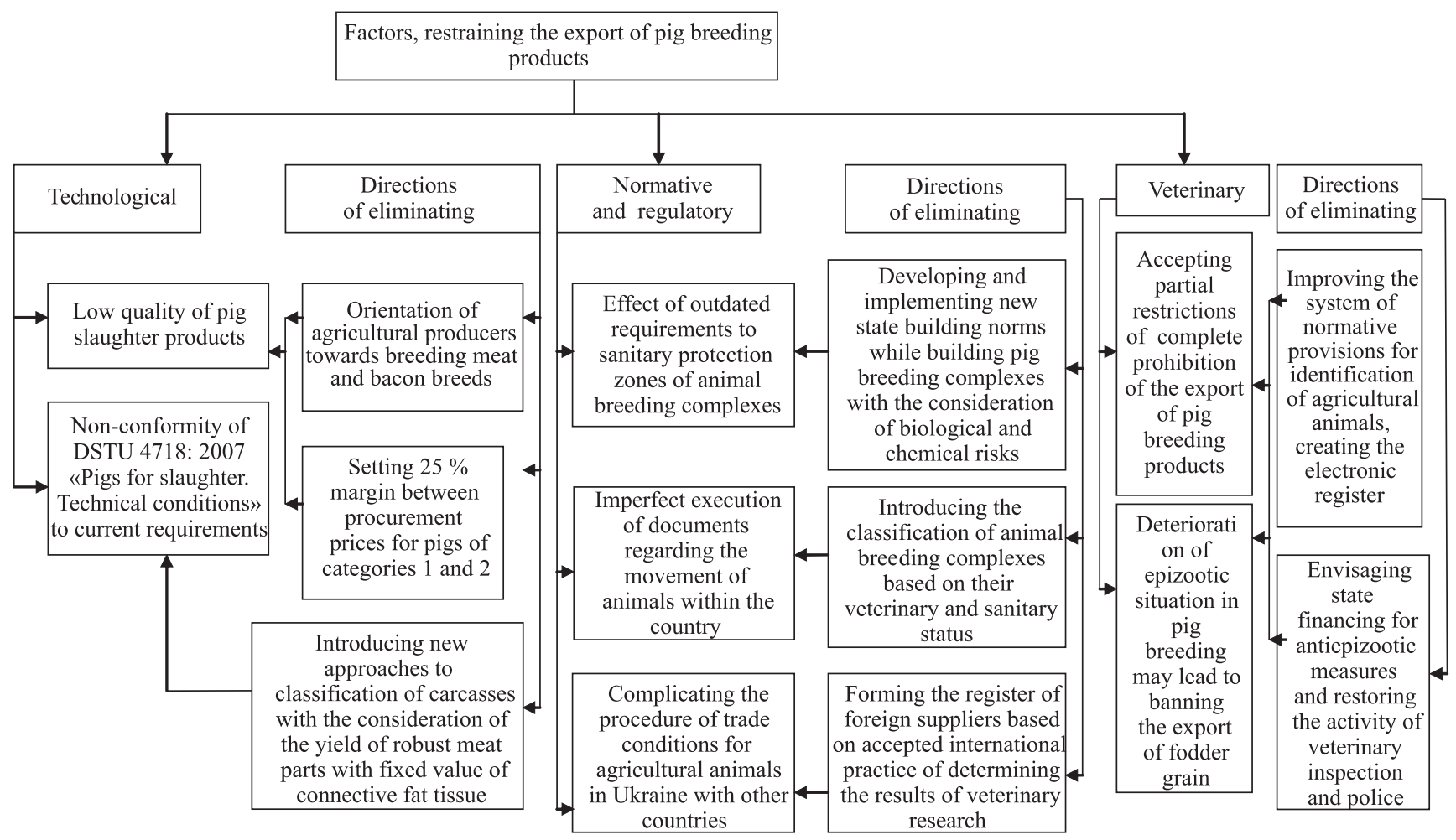

The main groups of factors, restraining the export of pig breeding products and the directions of their elimination. Source: elaborated by the authors

der. However, the organization of this feeding system requires fodder-preparing stations, pumps to move liquid mass, a bulk system of pipes and feeders. As a result, there are higher exploitation expenses to maintain this equipment running in proper sanitary and hygienic state. In addition, in cold season there are possible lung diseases of animals due to higher humidity in the premises with liquid feeding system.

Practice demonstrates that dry type of feeding is much cheaper. Its basic equipment is as follows: a tank to store fodder, transporters and feeders, also used to give water to animals. As a rule, over $70 \%$ of EU farms use dry feeding. Automatic distribution is recommended for the organization of feeding process and fast delivery of fodder without their quality loss. The introduction of such modern feeding systems makes it possible to have stable and forecast gain of 425-450 g/day per one piglet during finishing (feeding from 8 to $25 \mathrm{~kg}$ of live bodyweight) and 720-730 g/day per one porker (from 25 to $100-115 \mathrm{~kg}$ of live bodyweight) [27].

It is evident that the main factor of expanding the export potential of pig breeding industry should be the procurement price which reflects quality properties of pig slaughter products. At present the difference between the price of categories one and two is insignifi- cant which does not stimulate the production of meat and bacon breeds. We believe that the difference in the procurement price should be at least $25 \%$.

Current standard DSTU 4718:2007 «Pigs for slaughter. Technical conditions» does not facilitate solving this issue, as it does not consider a number of indicators: pre-slaughter live bodyweight of a pig; carcass weight, fat thickness; state of muscle tissue development. We believe that the main indicator, which may be reasonably laid into the foundation of current standards, is the yield of full-fledged meat parts with fixed weight of connective fat tissue [28].

As for normative and regulatory factors, restraining the activation of export activity of commodity producers of the industry under investigation, we will consider them within the framework of European integration of the country. Having endorsed the political part of the EU Association Agreement, Ukraine took the obligation of deregulating some kinds of economic activity, taking measures regarding the support of trade and harmonizing national legislation on some issues with the EU legislation. In particular, the following should be adjusted to the EU requirements in terms of directions, regulating the production and trade of pig breeding products: veterinary and sanitary rules for pig breed- 
ing farms; approval documentation for transportation of animals and the rules of bringing pigs from other countries.

It has been determined that current requirements to establishing sanitary protection zones are outdated and pose a severe problem for most pig breeding farms which actually have to violate these requirements. Therefore, there is an urgent need in Ukraine to elaborate modern methodology of establishing sanitary protection zones and minimizing veterinary breaks with the consideration of the impact of different factors, including type of production (a sow farm, a finishing complex or a closed loop farm), numbers of head, requirements of ecologic management. New state building norms while building pig breeding complexes, based on biological and chemical risks, should be elaborated to solve the abovementioned issues.

It should be noted that a complicated epizootic situation in Ukraine, in particular, the epidemic of African swine fever, hinders enhancing our positions on current sales markets and establishing new ones. In addition to Armenia, in 2016 this was the reason why Russia, Belarus, Moldova and Romania refused from Ukrainian pork, and at the end of 2017 this list of countries was prolonged by Hungary [29].

Certainly, the closure of Russian market was the most tangible for domestic suppliers of pork, but it is not reasonable to explain the loss of external markets only by spreading of African swine fever, as this reason for the prohibition was mostly declarative.

As for other countries, the prohibition to export pork of Ukrainian origin to Hungary, Romania and Belarus was almost not noted in the export of pork. For instance, Belarus blocks trade with the regions, where African swine fever is spreading most actively, but this country has not been a significant market of pork sale for Ukraine, and since 2015 Ukraine has not traded pork with this country.

Romania and Hungary, similar to other EU countries, have not been «open» for Ukrainian pork. At the same time, although traders note increased interest to these markets, it is exclusively due to their «trendy» nature.

On the other hand, the loss of markets of Moldova and Armenia was more tangible. For instance, in 2014 Moldova was the main sales market which covered almost $54 \%$ of annual volumes of pork export -5 thousand tons with the cumulative value of over USD 14 million, Armenia was among three main sales markets in 2016, as in January-August over 0.6 thousand tons of pork with the cost of USD 0.93 million were exported to this country.

We believe that in the absence of any signs of African swine fever and active demand for Ukrainian pork from Moldova at the level of 2014 and Armenia at the level of 2016, Ukraine could have sold additional 6 thousand tons of fresh, cooled or frozen pork meat to these external markets, and obtained additional USD 12 million for it.

However, in case of Moldova, the spreading of African swine fever is not the only reason, complicating external trade of pork: contrary to tangible deficit of Ukrainian own pork, agricultural producers, breeding pigs, have a negative ratio, which has become more organized, to the intake of import raw materials, regardless of their origin. For instance, in 2016 there were organized protests of agricultural commodity producers which forced the Ministry of Economy of Moldova to increase import levy for meat and milk products from Ukraine [22].

Obviously, in order to realize the possibility of exporting pig breeding products to the EU member-states, sanitary-veterinary services and agricultural commodity producers of our country should localize and eliminate the disease agents, and make sure that no case of African swine fever is registered for three years. Currently Ukraine fails to control African swine fever due to the shortage of qualified specialists. In addition, there is no identification and registration of agricultural animals in the country, which makes it impossible to track their movements [30].

In addition, financial foundation should be formed to fight and prevent African swine fever and ensure legislative provision for the activity of restored veterinary medicine service.

Best practices of other countries demonstrate that in such conditions quoting is an efficient lever of regulating import of products, the efficacy of which is ensured on condition of long-term application. We believe that the introduction of quotas should be based on annual analysis of the tempo of increasing domestic pork production and the volumes of its consumption. After achieving relevant parameters of production and consumption the quotas should be gradually decreased. At the same time, the import of frozen and cooled pork to the domestic market is also regulated by restraining levies, which are a limiting instrument for import. Obviously, the mentioned instruments are efficient and will promote the development and 
enhancing competitive advantages of domestic pig breeding production.

It is noteworthy that African swine fever has not affected export of live pigs, as all the batches of animals in slaughter condition are supplied to Georgia. For instance, in 2017 Ukrainian producers earned $43 \%$ more than in the previous year, while exporting live pigs. Although the volumes of external supplies of live animals increased insignificantly $(+8 \%$ to 2016), due to higher selling price they managed to earn over USD 4.5 million. At the same time, Ukrainian pig breeding farms spent almost the same amount to procure pedigree and hybrid pigs from abroad to enhance breeding potential [31].

We have systematized additional negative factors, caused by the import of live pigs. For instance, as live pigs are imported to our country for finishing with subsequent slaughter for prices, lower than those of domestic producers, it disrupts the development cycle of domestic animal breeding. Even full cycle enterprises have recently acquired the tendency of re-equipping sow farms into finishing complexes. It is much more profitable to finish imported pigs than breed your own animals. Therefore, an enormous segment of animal breeding is getting lost, and the development of the investigated industry becomes impossible without it.

The introduction of the system of administrative and fiscal measures of protecting domestic market and commodity producers in the external market of pig breeding products should be started with the elaboration of the relevant regulations, in particular, Technical regulations of requirements to production and the quality of raw meat materials. In our opinion, it should state the main normative and regulatory principles regarding export-import of pig slaughter products. For instance, the transportation of meat products across Ukraine's border is allowed only at the checkpoints on railway and automobile stations, in sea and river ports with state border veterinary control; during international transportation raw meat materials are accompanied with the original veterinary certificates, issued by the representative of the state veterinary service of the country of their origin (in case of import) and official veterinary specialist; determination of conditions of using raw meat, imported into Ukraine, is the competence of state veterinary surveillance bodies; the persons, guilty of violating veterinary rules of international and internal transportation of raw meat, should be held responsible in accordance to the international agreements and the legislation of Ukraine.
The need to stimulate export, to increase the share of products with a high level of processing in its structure, and enhancing the competitiveness of domestic products in external markets is conditioned by the relevance of export as a catalyst of economic development which will promote the increase in production volumes, higher taxation inputs to the budget and creating additional working places [32].

Therefore, in current conditions the elaboration of measures to ensure the access to the markets of other countries should be conducted with the consideration of relevant export-institutional environment. The main directions of supporting the export of domestic agrarian products should become as follows: facilitating export procedures; expanding assortment and accessibility of financial services; developing the supporting infrastructure; informational support for exporters; conducting research and implementing support programs. The development of infrastructure should be ensured via creating trade representations and activating their work, and the financial-economic sphere - via the combination of crediting and insurance coverage which will allow realizing the abovementioned directions. We believe that the activity of the system of credit-insurance institute and trade representations should be carried out in a single complex, in a single chain, via determining the potential market and financial-insurance support for the export.

It is evident that within the framework of the current model of economic development the state strategy should be based on balanced combination of direct state stimulation and support for private initiative. The following mechanisms may be distinguished among the methods of state stimulation: direct state support for export with the purpose of enhancing industrial potential in the industries, which have relevant possibilities to enter export markets; internal development and modernization of agrobusiness, changing the development strategy to enhance their market positions and create competitive products. Global practice shows the division into direct and indirect support of export. It is reasonable to apply direct support for companies, which intend to enter the external market, or for subjects with currently active export activity. Direct support is most frequently given via financial and nonfinancial instruments. The state gives indirect support to producers, who are on export and pre-export stage of development. Here the state may also foresee different financial and other non-financial levers.

The measures of direct financial support for export activity include as follows: long- and middle-term 
crediting of export; guarantees for export transactions; insuring export loans from commercial and political risks; reimbursing some percentage rates from export loans. The implementation of financial measures on the part of the state comes to state structures taking the responsibility for financial activity of national export companies, facilitating the access to financial resources, enhancing the conditions of financing. Taking into consideration the fact that international practice prohibits direct financing for state stimulation, for instance, via state financing for export loans, this requirement is especially strictly reflected in the rules of the Organization for Economic Cooperation and Development (OECD) which requires searching for more complicated ways of financial support.

We believe that the activity in the sphere of financial support should be conducted by specialized institutions - export-crediting agencies (ECA) and exportimport bank (Ukreximbank). In 2018 the ECA in the form of a private joint-stock company (PJSC) was created in Ukraine to protect Ukrainian exporters from the risks of non-payments, financial losses and accessible financing. Relevant functions of the ECA are insurance, reinsurance and providing guarantees pursuant to the agreements, ensuring the development of export. In addition, it will also take part in implementing partial compensation of the interest rate of the export loan and providing consultations to exporters.

We believe that the relevant tasks of the ECA are providing guarantees or insurances first and foremost: firstly, for loans of financial institutions to buyers in importing countries, and secondly, for non-payments on contracts with payments in installments (so called commercial loans, given to the buyer by the exporter). In addition, the ECA may also give loans to importers to finance the procurement of products («bound» export loans) and finance exporters.

Current systems of supporting export in different countries may be divided into three groups: the first group is in effect in the countries, where all the export-supporting activity is conducted via insurance agencies (EU member-states); in the second group, the main support for export is given via export-import banks (the USA, Brazil); the third group - via mixed systems (China, Japan). The development of a mixed system is reasonable for Ukraine, as it will both balance the conditions of accessing the credit resources, and envisage partial financing using state finances for the implementation of the development strategy for agrarian sector.
Ukraine's trade representations abroad may be considered a relevant instrument of promoting export development. At the same time, the organizational mechanisms of realizing their main functions should be improved. It is reasonable to establish a chain which would unite the procedures of determining export market and a buyer, and obtaining export loan and its insurance in terms of promoting a project by the trade representation immediately in the country of its location.

\section{CONCLUSIONS}

The study has determined that domestic commodity producers have potential advantages for the expansion of the export of pig breeding products in the form of relatively cheap fodder, logistics and labor force, but these are not used to the fullest degree. It was established that regardless of global tendencies of decrease in the level of procurement prices for pork, the remarkable fact about Ukraine is that due to considerable depreciation of hryvnia compared to the leading currencies of the world, the rate of procurement prices is less than 1 euro/kg of live bodyweight, which is one of its competitive advantages.

The results of estimating competitiveness of the main kinds of meat products - pork, beef and poultry meat - demonstrated the absence of competitive advantages in external markets of pig breeding products and insufficient food independence; the current level of relative competitiveness of beef and veal has been achieved via reduction of domestic demand and increased export supplies within two recent years of the study; poultry meat has higher competitive advantages, thus, due to expanding industrial potential of poultry meat industry, the food independence of the country is getting enhanced.

The study revealed that, contrary to other markets of meat products, the domestic market of pork has a high level of dependence on import. Additional negative factors, caused by the import of live pigs, have been systematized, revealing that as live pigs are imported to our country for finishing with subsequent slaughter for prices, lower than those of domestic producers, it disrupts the development cycle of domestic animal breeding.

Thus, in current conditions the elaboration of measures to ensure the access to markets of other countries should be conducted with the consideration of relevant export-institutional environment. The main directions of supporting the export of domestic agrarian products should become as follows: facilitating export proce- 
dures; expanding assortment and accessibility of financial services; developing the supporting infrastructure; informational support for exporters; conducting research and implementing support programs.

In our opinion, the state support should envisage the aid in finding crediting and subsidies for interest rates to decrease the total cost of financing for operational and investment kinds of activity. The state should also support exporters' implementation of the requirements of importing countries regarding certification and registration of the products, which is rather a cost-consuming activity, requiring considerable investments and knowledge of international trade rules from exporters. It is evident that the state should invest in the creation of a modern export infrastructure for agrobusiness, including the databases of partners and buyers, and take part in the organization and support in holding specialized exhibitions and other trade measures regarding the entrance of agrarian products to external markets. We believe that the abovementioned measures will allow ensuring the stimulation of export potential in terms of the main directions of activity, starting from optimization of industrial costs and decreasing investment losses, and delivering the products to the end sales markets.

\section{Чинники забезпечення конкурентоспроможності продукції свинарства України на зовнішніх ринках}

М. І. Ібатуллін ${ }^{2}$, О. М. Варченко ${ }^{1}$, І. В. Свиноус ${ }^{1}$, О. В. Климчук ${ }^{3}$, О. О. Драган ${ }^{1}$, I. О. Герасименко ${ }^{1}$

${ }^{1}$ Білоцерківський національний аграрний університет, 09117, Біла Церква, Пл. Соборна, 8/1, Україна

${ }^{2}$ Національний університет біоресурсів і природокористування,

03041, Київ, Вул. Героїв Оборони, 11, Україна

${ }^{3}$ Вінницький національний аграрний університет, 21008, Вінниця, Вул. Сонячна, 3, Україна

e-mail:omvarchenko@ukr.net, isvinous@ukr.net; klymchukov@ukr.net

Мета. Обгрунтування напрямів активізації експортних операцій на ринку продукції свинарства, визначення індикаторів конкурентоспроможності основних видів м'яса та відносної конкурентоспроможності продукції свинарства у провідних країнах світу на основі ідентифікації стримувальних чинників експорту української продукції свинарства та розробки пропозицій щодо нівелювання їх негативного впливу на динаміку зовнішньоекономічної діяльності галузі. Методи. Методичні підходи дослідження базувалися на інформації щодо обсягів зовнішньої торгівлі, що використовуються, в основному, для міжнародних порівнянь і визначаються для окремого товару або товарної групи. При оцінюванні конкурентних переваг продукції свинарства нами розраховано показники відносної експортної конкурентоспроможності (Relative Export Advantage Index, $R X A)$, індекс відносної залежності від імпорту (Relative Import Penetration Index, $R M P$ ) та індекс відносних торговельних переваг (Relative Trade Advantage Index, RTA). У дослідженні здійснено комплексний порівняльний аналіз основних видів м'ясної продукції на зовнішньому ринку за моделлю «продовольча незалежність - конкурентоспроможність». У якості показника продовольчої незалежності використано індекс продовольчої незалежності, а узагальнюючим показником конкурентоспроможності окремих видів м'ясної продукції - модифікований індекс Баласса. Встановлено, що рівень продовольчої незалежності доцільно визначати на основі продовольчого самозабезпечення у межах 70$80 \%$ від товарних ресурсів внутрішнього продовольчого ринку. При проведенні дослідження нами використано інформаційну базу Державної служби статистики України та ФАО щодо обсягів експорту-імпорту продукції свинарства. Результати. Доведено, що для продукції свинарства України на зовнішніх ринках відсутні конкурентні переваги та встановлено недостатню продовольчу незалежність за умови наявності ознак потенційних переваг для розширення експорту, зокрема, дешевих кормів та логістики. При цьому істотне зниження курсу гривні, відносно іноземних валют провідних країн світу, створює передумови для успішного просування свинини українських товаровиробників як на внутрішньому, так і зовнішньому ринках. Обгрунтовано необхідність налагодження моніторингу щодо виконання критеріїв продовольчої незалежності, а також диверсифікації експортної спеціалізації країни. У довгостроковій перспективі доцільно оптимізувати рівень захищеності ринку продукції свинарства, стимулювати вітчизняне виробництво, поширення інструментів державної підтримки «зеленого кошика». Доведено, що основними напрямами підтримки експорту вітчизняної аграрної продукції повинні стати: спрощення проходження експортних процедур; розширення асортименту та доступності фінансових послуг; розвиток інфраструктури підтримки; інформаційна підтримка експортерів; проведення досліджень та реалізація програм підтримки, діяльність системи кредитно-страхового інституту та торгових представництв повинна здійснюватися в єдиному комплексі через визначення потенційного ринку та фінансово-страхового сприяння експорту. Висновки. Розроблено та апробовано методику двокритеріального аналізу стану внутрішнього ринку м'ясопродукції на основі використання показників продовольчої безпеки та міжнародної конкурентоспроможності, що сприятиме проведенню комплексної оцінки позицій окремих видів продукції на зовнішньому ринку. Модель двокритеріального аналізу дозволяє обгрунтувати дієві інструменти державного регулювання та захисту відповідного ринку продукції. Методика двокритеріального ана- 
IBATULLIN et al.

лізу м'ясопродукції має універсальний характер, тобто може бути використаною для визначення позицій на зовнішньому ринку для різних товарних груп. Результати оцінювання конкурентоспроможності основних видів м'ясної продукції - свинини, яловичини та м'яса птиці - дозволили встановити відсутність конкурентних переваг на зовнішніх ринках продукції свинарства та недостатню продовольчу незалежність. Систематизовано стримувальні чинники нарощення експорту свинини, які об'єднано в три основні групи: технологічні; нормативно-правові; ветеринарні та напрями їх усунення. Розроблено заходи щодо створення сприятливого експортно-інституціонального середовища та запропоновано основні напрями підтримки експорту вітчизняної продукції свинарства.

Ключові слова: конкурентні переваги, торговельні переваги, експорт, імпорт, продукція свинарства, експортнокредитні агентства, підтримка експорту, інфраструктура експорту.

\section{Факторы обеспечения конкурентоспособности продукции свиноводства Украины на внешних рынках}

М. И. Ибатуллин ${ }^{2}$, А. Н. Варченко ${ }^{1}$, И. В. Свиноус ${ }^{1}$, А. В. Климчук ${ }^{3}$, А. А. Драган ${ }^{1}$, И. А. Герасименко ${ }^{1}$

${ }^{1}$ Белоцерковский национальный аграрный университет, 09117, Белая Церковь, Пл. Соборная, 8/1, Украина

${ }^{2}$ Национальный университет биоресурсов и природопользования,

03041, Киев, Ул. Героев Обороны, 11, Украина

${ }^{3}$ Винницкий национальный аграрный университет, 21008, Винница, Ул. Сонячна, 3, Украина

e-mail: omvarchenko@ukr.net, isvinous@ukr.net; klymchukov@ukr.net

Цель. Обоснование направлений активизации экспортных операций на рынке продукции свиноводства, определения индикаторов конкурентоспособности основных видов мяса и относительной конкурентоспособности продукции свиноводства в ведущих странах мира на основе идентификации сдерживающих факторов экспорта украинской продукции свиноводства и разработки предложений по нивелированию их негативного влияния на динамику внешнеэкономической деятельности отрасли. Методы. Методические подходы исследования базировались на информации об объемах внешней торговли, используемых, в основном, для международных сравнений и определяются для отдельного товара или товарной группы. При оценке конкурентных преимуществ продукции свиноводства нами рассчитаны показатели относительной экспортной конкурентоспособности (Relative Export Advantage Index, RXA), индекс относительной зависимости от импорта (Relative Import Penetration Index, RMP) и индекс относи- тельных торговых преимуществ (Relative Trade Advantage Index, RTA). В исследовании осуществлен комплексный сравнительный анализ основных видов мясной продукции на внешнем рынке по модели «продовольственная независимость - конкурентоспособность». В качестве показателя продовольственной независимости использовано индекс продовольственной независимости, а обобщающим показателем конкурентоспособности отдельных видов мясной продукции - модифицированный индекс Баласса. Установлено, что уровень продовольственной независимости целесообразно определять на основе продовольственного самообеспечения в пределах 70-80\% товарных ресурсов внутреннего продовольственного рынка. При проведении исследования нами использовано информационную базу Государственной службы статистики Украины и ФАО по объемам экспорта-импорта продукции свиноводства. Результаты. Доказано, что для продукции свиноводства Украины на внешних рынках отсутствуют конкурентные преимущества и установлено недостаточное продовольственную независимость при условии наличия признаков потенциальных преимуществ для расширения экспорта, в частности, дешевых кормов и логистики. При этом существенное снижение курса гривны, в отношении иностранных валют ведущих стран мира, создает предпосылки для успешного продвижения свинины украинских товаропроизводителей как на внутреннем, так и внешнем рынках. Обоснована необходимость налаживания мониторинга по выполнению критериев продовольственной независимости, а также диверсификации экспортной специализации страны. В долгосрочной перспективе целесообразно оптимизировать уровень защищенности рынка продукции свиноводства, стимулировать отечественное производство, распространение инструментов государственной поддержки «зеленой корзины». Доказано, что основными направлениями поддержки экспорта отечественной аграрной продукции должны стать: упрощение прохождения экспортных процедур; расширение ассортимента и доступности финансовых услуг; развитие инфраструктуры поддержки; информационная поддержка экспортеров; проведение исследований и реализация программ поддержки, деятельность системы кредитно-страхового института и торговых представительств должна осуществляться в едином комплексе через определение потенциального рынка и финансово-страхового содействия экспорту. Выводы. Разработана и апробирована методика двукритериальная анализа состояния внутреннего рынка мясопродукции на основе использования показателей продовольственной безопасности и международной конкурентоспособности, что будет способство-вать проведению комплексной оценки позиций отдельных видов продукции на внешнем рынке. Модель двукритериальная анализа позволяет обосновать эффективные инструменты государственного регулирования и 


\section{FACTORS OF ENSURING THE COMPETITIVENESS OF UKRAINE'S PIG BREEDING PRODUCTION}

защиты соответствующего рынка продукции. Методика двукритериальная анализа мясопродукции имеет универсальный характер, то есть может быть использована для определения позиций на внешнем рынке для различных товарных групп. Результаты оценки конкурентоспособности основных видов мясной продукции свинины, говядины и мяса птицы - позволили установить отсутствие конкурентных преимуществ на внешних рынках продукции свиноводства и недостаточную продовольственную независимость. Систематизированы сдерживающие факторы наращивания экспорта свинины, которые объединены в три основные группы: технологические; нормативно-правовые; ветеринарные и направления их устранения. Разработаны мероприятия по созданию благоприятного экспортно-институциональной среды и предложены основные направления поддержки экспорта отечественной продукции свиноводства.

Ключевые слова: конкурентные преимущества, торговые преимущества, экспорт, импорт, продукция свиноводства, экспортно-кредитные агентства, поддержка экспорта, инфраструктура экспорта.

\section{REFERENCES}

1. Yatsenko OM, Nevzghliad NH. The global trends of the agri-food market: the prospects for Ukraine, 2015;(27):54-62.

2. Varchenko O, Svynous I, Grynchuk Y, Tkachenko K, Shust $O$. The strategy of developing agricultural supply chain in terms of food security in Ukraine. Inter. J. Supp. Chain Managem., 2018;7(5):657-66. https://ojs. excelingtech.co.uk/index.php/IJSCM/article/view/2358.

3. Shpychak OM. Price formation problems in the context of the purchasing ability of the population and inflation processes. Ekonomika APK, 2016;(6):59-70 (in Ukrainian).

4. Ibatullin MI. World market of production of swine breeding and place of Ukraine in it, Bul. Agricult. Sci., 2017;(1): 62-7. https://doi.org/10.31073/agrovisnyk201701-12.

5. Han J, Lu H, Trienekens JH, Omta SWF. The impact of supply chain integration on firm performance in the pork processing industry in China. Chin. Managem. Stud., 2017;7(2):230-52. https://doi.org/10.1108/CMSJun-2011-0034.

6. Schulze B, Spiller A, Theuvsen L. A broader view on vertical coordination: Lessons from German pork production. J. Chain Network Sci., 2007;7(1):35-53. https:// doi.org/10.3920/JCNS2007.x076.

7. Szymańska EJ. The development of the pork market in the world in terms of globalization. J. Agribus. Rural Development., 2017;4(46):843-50. doi: 10.17306/J. JARD.2017.00362.

8. Nagy L, Hryszko K, Rycombel D. Structural changes in the Polish and Hungarian pig sectors since EU accession. Potori, Chmielinski, Fieldsend (eds): Structural changes in Polish and Hungarian agriculture since EU accession: Lessons learned and implications for the design of future agricultural policies. Research Institute of Agricultural Economics, Budapest. 2014:165-83.

9. Rumánková L. Examination of market structure in selected livestock agri-food chains in the Czech Republic. Acta Universit. Agricult. Silvicult. Mendel. Brunen., 2012;60(7):243-58. doi: 10.11118/actaun201260070243.

10. Varchenko O, Svynous I, Grynchuk Y, Khakhula B, Ibatullin $M$. Improvement of eco-taxation of good producers of pig husbandry in Ukraine. Academy of Accounting and Financial Studies Journal., 2018;22(5):1-11.

11. Dunay A, Vinkler-Rajcsányi K. Hungarian pig sector: Actual problems and prospects for the future development. Acta Universit. Agricult. Silvicult. Mendel. Brunen., 2016;64(6):1879-88. doi: 10.11118/actaun201664061879.

12. Slaboch J, Kotyza P. Comparison of self-sufficiency of selected types of meat in the Visegrad countries. J. Central Europ., 2016;17(3):793-814. doi: 10.5513/JCEA 01/17.3.1777.

13. Tamaš $V$, Bečvařova $V$. Development of consumer preferences on the significant markets of pig meat. Acta Universit. Agric. Silvicult. Mendel. Brunen., 2013;61(7):2875-82. doi: 10.11118/actaun201361072875.

14. Merlino VM, Massaglia S, Borra D. Analysis of European consumer awareness for identifying animalfriendly meat. Quality - Access to Success. Supplement 2; 2019;20:388-95.

15. Wageli S, Janssen M, Hamm U. Organic consumers' preferences and willingness-to-pay for locally produced animal products. Inter. J. Consum. Stud., 2016;40(3):35767. doi: $10.1111 /$ ijcs.12262.

16. Balassa BA. A stages approach to comparative advantage. Reprinted with permission from Economic Growth and Resources, edited by Irma Adelman, Proceedings of the Fifth Congress of the International Economic Association, Tokyo, Japan, 1977;4:121-56.

17. Balassa BA. A stages approach to comparative advantage. Staff working paper; no. SWP 256. Washington, D.C.: The World Bank. URL: http://documents.worldbank.org/ curated/en/811771468765933550/A-Stages-approachto-comparative-advantage.

18.Török Á. Export competitiveness and the catch-up process of Hungary (1996-2001). Competitiveness Review: An Inter. Busin. J. 2002;18(1/2):131-53. doi: 10.1108/10595420810874646.

19. Simo D, Mura L, Buleca J. Assessment of milk production competitiveness of the Slovak Republic within the EU27 countries. Agric. Econom., 2016;62(10):482-92. doi: 10.17221/270/2015-AGRICECON.

20. Livestock and Poultry: World Markets and Trade World Production, United States Department of Agriculture, Foreign Agricultural Service, October 11, 2018. URL: https://downloads.usda.library.cornell.edu/usdaesmis/ 


\section{IBATULLIN et al.}

files/73666448x/mg74qq69r/j6731729p/livestock_ poultry.pdf.

21. Livestock and Poultry: World Markets and Trade. United States Department of Agriculture, Foreign Agricultural Service, April 9, 2019. URL: https://apps.fas.usda.gov/ psdonline/circulars/livestock_poultry.pdf.

22. Kravets IV. Modern tendencies of pork production development in Ukraine and in the world. Efektyvna ekonomika, 2018;(10). doi: 10.32702/2307-2105-2018. 10.68

23. Varchenko O, Hrynchuk $V$. Trends of forming agri-food chains of added value in Ukraine. International Scientific Days 2018. «Towards Productive, Sustainable and Resilient Global Agriculture and Food Systems». May 16-17, 2018, Nitra, Slovak Republic. 881-91.

24.Udovenko NM, Gryshchenko NP, Shepelev Sun. Regulation of the Ukrainian pork market in the context of European integration: «Kondor» Publishing House, 2017. 372 p. https://nubip.edu.ua/sites/default/files/u204/2017_ monogr_sviny.pdf.

25. Khare V, Khare A. Modern Approach in Animal Breeding by Use of Advanced Molecular Genetic Techniques. Inter. J. Livestock Res. 2017;7(5):1-22. doi: 10.5455/ ijlr.20170404010154.

26. Sausheva OS, Gorin VA, Zemskova ES. Resourcesaving technologies in agriculture as a tool for ensuring food security: the experience of the European Union. Fundamentalnyie issledovaniya. 2016;6(1):212-7.

27. Kim JS, Ingale SL, Baidoo SK, Chae BJ. Impact of Feed Processing Technology on Nutritional Value of Pigs Feed: A Review. Anim. Nutrit. Feed Technol. 2016;16(2):18196. doi: 10.5958/0974-181X.2016.00017.2.

28. Kostetsky YaI. Impact of globalization on transformational processes in agrarian sector of Ukraine. Scient. bull. of Uzhhorod Nat. Univer. 2016;6(2):28-31 (in Ukrainian).

29. Wallenbec A, Strandberg E, Rydhmer L, Röcklinsberg H, Ljung M, Ahlma T. Preferences for pig breeding goals among organic and conventional farmers in Sweden. Organic Agric. 2016;6(3):171-82. doi: 10.1007/s13165015-0125-3.

30. Kalinchyk S, Alekseenko I, Kalinchyk M. Problems of Ukrainian pig farming in the world market environment. Agrosvit. 2017;(12):9-14.

31. Nepriadkina $N V$. Foreign trade development between Ukraine and the EU in agricultural sphere: specifics and prospects. Visn. Harkiv. nats. un-tu im. V.N. Karazina. 2018:60-5.

32. Zhadko KS, Nosova TI. Problematic aspects of the efficiency of production and sales of pork meat in conditions of complex epizootic state. Efektyvna ekonomika. 2018. -6 c. 